\title{
PENGARUH SENAM ERGONOMIS TERHADAP DISTRESS LANSIA DENGAN DIABETES MELLITUS
}

\author{
Akhmad Fathoni ${ }^{1}$, Dewi Purnamawati ${ }^{2}$, Irwina Syafitri ${ }^{3}$ \\ 1,2,3 Jurusan Keperawatan, Poltekkes Kemenkes Mataram, Indonesia
}

\begin{abstract}
Abstrak
Latar Belakang: Penyandang Diabetes Mellitus di dunia mencapai 10,3 juta orang pada usia 20-79 tahun. Penyandang Diabetes Mellitus menjalani ketegangan kronik hidup dengan perawatan diri kompleks dan berisiko tinggi mengalami depresi dan Distress Emosional spesifik karena DM. Data penyandang DM di Puskesmas Cakranegara tahun 2018 sebanyak 628 orang dalam kisaran umur 4575 tahun. Metode: Desain penelitian ini menggunakan Pra Eksperimental One Group Pretest-Posttest Design. Populasi dalam penelitian ini adalah 113 lansia DM. Sampel yang didapatkan sebanyak 30 lansia dengan DM. Tehnik pengambilan sampel yaitu dengan tehnik Purposive Sampling. Cara pengumpulan data menggunakan kuisioner. Penelitian ini dianalisis menggunakan uji Wilcoxon dengan hasil $(\rho=0.000)$. Hasil: Hasil penelitian menunjukkan sebelum diberikan intervensi senam ergonomis, sebagian besar responden berada pada kategori distress sedang yaitu 25 orang $(83,33 \%)$. Setelah diberikan intervensi senam ergonomis, sebanyak 16 orang berada pada kategori distress sedang $(53,33 \%)$, dan 14 orang berada pada kategori distress ringan (46,67\%). Hasil penelitian didapatkan $\rho=0.000$. Kesimpulan: Ada pengaruh senam ergonomis terhadap distress lansia dengan Diabetes Mellitus di Kelurahan Selagalas Wilayah Kerja Puskesmas Cakranegara.
\end{abstract}

Kata Kunci: Senam Ergonomis, Distress, Diabetes Mellitus

\section{THE EFFECT OF THE ERGONOMIST EXERCISE TOWARDS DISTRESS OF ELDERLY WITH DIABETES MELLITUS}

\begin{abstract}
Background: People with Diabetes Mellitus in the world has reached 10,3 millions of people on the age of 20-79 years old. The people who has Diabetes Mellitus undergo the chronic life tension with the complex self-care and high risky to depression and Emotional Distress specifically because of Diabetes Mellitus. The data of the Diabetes Mellitus at shows Cakranegara Community Health Center 2018 abou 628 people had it on the age of 45-75 years. Methods: The research design was Pra Eksperimental One Group Pretest-Posttest Design. The population in this research are 113 of Diabetes Mellitus elder. The samples obtained is about 30 elder of Diabetes Mellitus. The sampling technique was Purposive Sampling. The data collectioning of distress scale was used the questionnaire. This reserach analyzed by Wilcoxon with result $(\rho=0.000)$. Results: The results shows before giving the Ergonomist Exercise intervention, most of the respondents on the moderate distress category about 25 respondents (83,33\%). After giving the Ergonomist Exercise intervention, about 16 respondents is on the moderate distress category $(53,33 \%)$, and about 14 respondents is on the mild distress category $(46,67 \%)$. The results obtained $\rho=0.000$. Conclusions: There's an effect of the ergonomist exercise to distress of the elder who has diabetes mellitus at Selagalas Regency of the working area of Cakranegara Community Health Center.
\end{abstract}

Key Words: Ergonomist Exercise, Distress, Diabetes Mellitus 


\section{PENDAHULUAN}

Diabetes Mellitus (DM) menurut Sudoyo dkk (2009) dalam Nurarif (2016) merupakan gangguan metabolisme yang ditandai oleh hiperglikemia yang berhubungan dengan abnormalitas metabolisme karbohidrat, lemak, dan protein yang disebabkan oleh penurunan sekresi insulin atau penurunan sensitivitas insulin atau keduanya dan menyebabkan komplikasi kronis mikrovaskuler, makrovaskuler, dan neuropati. Diabetes Mellitus (DM) merupakan suatu penyakit kronis dimana organ pankreas tidak memproduksi cukup insulin atau ketika tubuh tidak efektif dalam menggunakannya (WHO, 2016).

Diabetes Mellitus (DM) memiliki prevalensi yang tinggi menurut International Diabetes Mellitus Federation(IDF) Atlas tahun 2017 melaporkan bahwa prevalensi Diabetes Mellitus di Indonesia masih menunjukkan kecenderungan meningkat. Indonesia menjadi negara peringkat keenam di dunia setelah Tiongkok, India, Amerika Serikat, Brazil dan Meksiko dengan jumlah penyandang Diabetes Mellitus usia 20-79 tahun sekitar 10,3 juta orang (Depkes, 2018).

Jumlah penyandang Diabetes Mellitus (DM) berdasarkan hasil Riset Kesehatan Dasar tahun 2018 memiliki angka tertinggi terdapat di daerah DKI Jakarta sebesar 3,4\% dan terendah di NTT sebesar 0,9\%, sedangkan di NTB sebesar 1,6\% (Riskesdas, 2018). Prevalensi DM tertinggi di Mataram sebesar 1,7\%, dan terendah di Lombok Tengah sebesar 0,5\%. Penyakit Diabetes Mellitus (DM) menempati urutan ke 9 dalam 10 penyakit terbanyak di Puskesmas Provinsi NTB tahun 2017 (Profil Kesehatan NTB, 2017). Menurut data profil kesehatan Kota Mataram tahun 2015, prevalensi pasien Diabetes Mellitus (DM) tertinggi di Puskesmas Cakranegara sebanyak 334 orang, dan terendah di Puskesmas Ampenan sebanyak 16 orang (Profil Kesehatan Kota Mataram, 2015).

Peyandang DM di puskesmas Cakranegara pada tahun 2017 yang mengalami DM sebanyak 176 orang, pada tahun 2018 yang mengalami DM sebanyak 708 orang, berdasarkan data tersebut terjadi peningkatan penyandang DM di Puskesmas Cakranegara (Data Puskesmas Cakranegara). Perubahan life style kearah negatif seperti kurang aktifitas fisik, lebih sering mengkonsumsi fast food, junk food, dan faktor stress adalah beberapa faktor yang memicu tingginya angka kejadian Diabetes Mellitus (DM). Hal tersebut ditunjukkan dengan masuknya penyakit tersebut dalam 10 penyakit terbanyak di Provinsi NTB (Profil Kesehatan Provinsi NTB, 2017). Berdasarkan data Puskesmas Cakranegara tahun 2018 sebanyak 628 lansia mengalami DM dengan kisaran umur 45 sampai dengan lebih dari 75 tahun. Prevalensi peyandang DM meningkat seiring bertambahnya usia. Perubahan fisiologis normal karena pertambahan usia atau penuaan dapat menyamarkan manifestasi awitan DM. Pada lansia, kemampuan kerja dan kegiatan menurun. Semua organ di dalam tubuh mengalami penuaan, sehingga terjadi perubahan atau kemunduran fungsi-fungsinya. Hal ini merupakan akibat dari gabungan penurunan kemampuan fungsi berbagai organ dan sistem yang terdapat di dalam tubuh (Santoso \& Ismail, 2009). 
Seseorang dengan Diabetes Mellitus mengalami perubahan psikis diantaranya stress pada dirinya yang berkaitan dengan perawatan yang harus dijalani. Berdasarkan studi National Institute of Diabetes Mellitus and Digestive and Kidney Disease lansia dapat menyandang DM tipe 1 dan DM tipe 2. Penyandang DM tipe 1 maupun tipe 2, menjalani ketegangan kronik hidup dengan perawatan diri kompleks dan berisiko tinggi mengalami depresi dan Distress Emosional spesifik karena DM (LeMone dkk, 2016).

Distress pada Diabetes Mellitus akan mempengaruhi upaya kontrol glukosa pada pasien DM. Manajemen Diabetes Mellitus dalam kehidupan sehari-hari dapat menjadi beban bagi penyandang DM, sehingga dapat menimbulkan perasaan frustrasi, marah, kewalahan, dan putus asa (Fisher dkk, 2010; dalam Lestari, 2016). Fisher (1982) dalam Nasriati (2013) Diabetes Mellitus dan stress merupakan dua hal yang saling mempengaruhi baik secara langsung maupun tidak langsung. Penatalaksanaan dalam pencegahan kemunduran fungsi dan organ lansia sangat diperlukan. Berdasarkan PERKENI (2015) penatalaksanaan DM memiliki 4 pilar yaitu edukasi, terapi nutrisi medis, jasmani/olahraga, dan terapi farmakologi.

Penatalaksanaan DM salah satunya adalah olahraga secara teratur yang terdiri dari setidaknya 150 menit per minggu (LeMone, 2016). Manfaat olahraga sama bagi setiap orang dengan atau tanpa DM yaitu meningkatkan kebugaran fisik, memperbaiki keadaan atau stress emosional, pengendalian berat badan, dan meningkatkakan kapasitas kerja (LeMone dkk, 2016). Latihan fisik atau olahraga untuk lansia yang dapat dilakukan misalnya senam kegel, yoga, taichi dan senam ergonomik (Sagiran, 2012).

Senam ergonomis merupakan suatu teknik senam untuk mengembalikan atau membetulkan posisi dan kelenturan sistem saraf dan aliran darah, memaksimalkan suplai darah ke otak, membuka sistem kecerdasan, sistem keringat, sistem pembakaran asam urat, kolesterol, gula darah, asam laktat, Kristal oxalate, sistem konversi karbohidrat, sistem pembuatan elektrolit atau ozon dalam darah, sistem kesegaran tubuh dan sistem kekebalan tubuh dari energi negatif/virus, dan sistem pembuangan energi negatif dari dalam tubuh. Jika tombol-tombol kesehatan telah dibuka maka akan terbebas dari pikun dini, kanker payudara, prostat, migrain, stres, kolesterol, kencing manis (Diabetes Mellitus), dan sebagainya (Wratsongko, 2015).

Menurut penelitian dari Diana Tri Lestari dkk (2016) yang berjudul pengaruh senam ergonomis terhadap distress Diabetes Mellitus, dapat disimpulkan bahwa senam ergonomis dapat menurukan skor distress Diabetes Mellitus yang dilakukan pada 30 responden dalam waktu 25 menit selama 6 hari berturut-turut. Penelitian lain dari Aisyiyah Hidayati (2018) yang berjudul pengaruh senam ergonomik terhadap tekanan darah lansia hipertensi di desa Peresak wilayah kerja Puskesmas Sedau tahun 2018 dengan 30 responden yang dilakukan selama 1 minggu sebanyak 6 kali perlakuan pada sore hari selama 23 menit, didapatkan hasil bahwa senam ergonomik dapat menurunkan tekanan darah pada lansia jika dilakukan dengan benar dan memberikan penanganan alternatif pada pasien secara non farmakologi. 
Berdasarkan studi pendahuluan dengan menyebar kuisioner pada 15 responden lansia DM didapatkan hasil 5 orang mengalami stress ringan, 7 orang mengalami stress sedang, dan 3 orang mengalami stress berat. Banyak lansia yang baru mengetahui dirinya mengalami Diabetes Mellitus. Penatalaksanaan yang diberikan adalah memberikan obat Diabetes Mellitus (DM). Lansia dengan stress berat merasa putus asa, tertekan, dan stress yang diakibatkan kadar gula darahnya masih tinggi meskipun sudah mengkonsumsi obat sehingga lansia merasa enggan untuk mengontrol gula darah secara rutin. Para lansia juga merasa tidak puas untuk mengkonsumsi makanan yang dianjurkan dari puskesmas. Program aktivitas senam berupa senam peregangan yang dilakukan pada program prolanis satu kali sebulan, serta diikuti oleh 20 lansia yang dilakukan dalam waktu 20 menit, lansia yang mengikuti program tidak sepenuhnya mengikuti kegiatan tersebut. Adapun senam ergonomis untuk mengatasi masalah distress lansia DM belum pernah dilakukan di Puskesmas Cakranegara. Tujuan penelitian ini yaitu untuk mengetahui Pengaruh Senam Ergonomis Terhadap Distress Lansia dengan Diabetes Mellitus di Kelurahan Selagalas Wilayah Kerja Puskesmas Cakranegara.

\section{METODE}

Penelitian ini menggunakan rancangan penelitian pre eksperimental yang bersifat kuantitatif tanpa kelompok kontrol dengan pendekatan One Group Pretest-Posttest Design. Tekhnik pengumpulan data menggunakan kuisioner Diabetes Distress Scale (DDS) dan buku catatan registrasi Puskesmas. Sampel dalam penelitian ini menggunakan Purposive Sampling. Analisis data dalam penelitian ini menggunakan analisis Statistic Non Parametric dengan menggunakan Uji Wilcoxon dengan data berbentuk ordinal dengan nilai $\rho$ value $<\alpha(5 \%)$ artinya Ha diterima dan Ho ditolak sedangkan jika nilai $\rho$ value $>\alpha(5 \%)$ maka Ha ditolak dan Ho diterima. 


\section{HASIL PENELITIAN}

Tabel 1. Distribusi Responden Meliputi Umur, Jenis Kelamin, Pendidikan, Pekerjaan, Lama Mengalami DM Dan Mengkonsumsi Obat Di Kelurahan Selagalas Wilayah Kerja Puskesmas Cakranegara, 26-30 Juni 2019 (N=30).

\begin{tabular}{|c|c|c|c|c|c|c|c|c|c|c|c|c|c|c|c|c|c|}
\hline Umur & $\mathbf{N}$ & $\%$ & $\begin{array}{l}\text { Jenis } \\
\text { kelamin }\end{array}$ & $\mathbf{N}$ & $\%$ & Pendidikan & $\mathbf{N}$ & $\%$ & Pekerjaan & $\mathbf{N}$ & $\%$ & Lama DM & $\mathbf{N}$ & $\%$ & $\begin{array}{l}\text { Konsumsi } \\
\text { obat }\end{array}$ & $\mathbf{N}$ & $\%$ \\
\hline $45-49$ & 9 & 30 & Perempuan & 12 & 40 & Pendidikan dasar & 17 & 56,67 & Bekerja & $\begin{array}{l}1 \\
9\end{array}$ & $\begin{array}{c}63,3 \\
3\end{array}$ & $0-1$ tahun & 21 & 70 & $\mathrm{Ya}$ & 14 & $\begin{array}{c}46,6 \\
7\end{array}$ \\
\hline $50-54$ & 4 & 13,33 & Laki-laki & 18 & 60 & $\begin{array}{l}\text { Pendidikan } \\
\text { menengah }\end{array}$ & 8 & 26,67 & $\begin{array}{l}\text { Tidak } \\
\text { bekerja }\end{array}$ & $\begin{array}{l}1 \\
1\end{array}$ & $\begin{array}{c}36,6 \\
7\end{array}$ & $2-3$ tahun & 8 & 26,67 & Tidak & 16 & $\begin{array}{c}53,3 \\
3\end{array}$ \\
\hline $55-59$ & 17 & 56,67 & & & & Pendidikan tinggi & 2 & 6,66 & & & & 4-5 tahun & 1 & 3,33 & & & \\
\hline & & & & & & Tidak sekolah & 3 & $\begin{array}{r}10,00 \\
\mathrm{~N}=\end{array}$ & & & & & & & & & \\
\hline
\end{tabular}

Tabel 2. Kategori Distress Lansia dengan DM Sebelum Intervensi Senam Ergonomis di Kelurahan Selagalas Wilayah Kerja Puskesmas Cakranegara, 26-30 Juni $2019(\mathrm{~N}=30)$.

\begin{tabular}{llcccccc}
\hline No & Kategori & Pretest & Persentase (\%) & Minimum & Maximum & Mean & Std. Deviation \\
\hline 1. & Ringan $(<2)$ & 5 & 16,67 & 1.3 & 2.9 & 2.423 & .4500 \\
\hline 2. & Sedang $(2,0-2,9)$ & 25 & 83,33 & & & & \\
\hline & Jumlah & 30 & 100 & 1.3 & 2.9 & 2.423 & .4500 \\
\hline
\end{tabular}

Tabel 2 menunjukkan pada pretest, kategori distress lansia dengan DM sebagian besar berada pada rentang nilai sedang sebanyak 25 orang $(83,33 \%)$.

Tabel 3. Kategori Distress Lansia Dengan DM Setelah Intervensi Senam Ergonomis Di Kelurahan Selagalas Wilayah Kerja Puskesmas Cakranegara, 26-30 Juni 2019 (N=30).

\begin{tabular}{llcccccc}
\hline No & Kategori & Posttest & Persentase (\%) & Minimum & Maximum & Mean & Std. Deviation \\
\hline 1. & Ringan $(<2)$ & 14 & 46,67 & 1.0 & 2.8 & 1.857 & .4337 \\
\hline 2. & Sedang $(2,0-2,9)$ & 16 & 53,33 & & & & .4337 \\
\hline & Jumlah & 30 & 100 & 1.0 & 2.8 & 1.857 & \\
\hline
\end{tabular}


Berdasarkan tabel 3. Hasil pengukuran posttest untuk nilai distress lansia dengan DM terbanyak berada pada kategori distress sedang sebanyak 16 orang dengan persentase $(53,3 \%)$. Dan terendah dengan kategori distress ringan sebanyak 14 orang dengan persentase $(46,7 \%)$.

Tabel 4. Hasil Uji Wilcoxon Pada Penelitian Pengaruh Senam Ergonomis Terhadap Distress Lansia Dengan Diabetes Mellitus Di Kelurahan Selagalas Wilayah Kerja Puskesmas Cakranegara, 26-30 Juni $2019(\mathrm{~N}=30)$.

\begin{tabular}{cccccc} 
& $\mathrm{n}$ & Minimum & Maximum & Mean & Std. Deviation \\
\hline pre test & 30 & 1.3 & 2.9 & 2.423 & .4500 \\
\hline post & 30 & 1.0 & 2.8 & 1.857 & .4337 \\
\hline \multicolumn{5}{c}{$\alpha=0.05, p$ value $=0.000$} \\
\hline
\end{tabular}

Tabel 4. menunjukkan bahwa nilai rata-rata pada pre test dan post test mengalami penurunan yaitu dari 2.423 menjadi 1.857. Dengan standar deviasi pada pre test yaitu 0.4500 dan pada post test yaitu 0.4337. Nilai maksimum pre test dan post test yaitu 2.9 dan 2.8. Berdasarkan hasil perhitungan menggunakan Uji Wilcoxon pada sistem komputerisasi SPSS 16.0 diperoleh hasil yaitu $p$ value $=0.000$ $<\alpha=0.05$, dimana hipotesis nol $\left(\mathrm{H}_{0}\right)$ ditolak atau hipotesis alternatif $\left(\mathrm{H}_{\mathrm{a}}\right)$ diterima yang artinya "Ada Pengaruh Senam Ergonomis terhadap Distress Lansia dengan Diabetes Mellitus di Kelurahan Selagalas wilayah kerja Puskesmas Cakranegara tahun 2019”.

\section{PEMBAHASAN}

Berdasarkan hasil penelitian yang telah dilakukan di Puskesmas Cakranegara dengan 30 responden lansia yang mengalami Distress Diabetes Mellitus ditemukan hasil rata-rata nilai distress lansia yang mengalami Diabetes Mellitus sebelum dilakukan senam ergonomis yaitu 2.423 dengan standar deviasi 0.4500 dan nilai minimum 1.3 serta nilai maksimum 2.9. Sebagian besar responden mengalami distress sedang yaitu sebanyak 25 lansia dengan persentase $(83,33 \%)$.

Menurut teori Siregar \& Hidajat (2017) distress pada diabetes dipengaruhi oleh kognitif, lama sakit, kepribadian dan faktor ekonomi. Adapun menurut Wardian (2015) menyebutkan faktor yang berhubungan dengan diabetes distress adalah usia, indeks masa tubuh, pelayanan kesehatan profesional dan efikasi diri. Tingkat distress dianalisis berdasarkan karakteristik responden yaitu umur, jenis kelamin, pendidikan, pekerjaan, lama DM, dan konsumsi obat DM. Diabetes Melitus merupakan penyakit kronik yang dapat dikaitkan dengan sebagai salah satu penyebab stres psikologis bagi klien DM (Wardian, 2015).

Umumnya manusia mengalami perubahan fisiologis yang secara drastis menurun dengan cepat setelah usia 40 tahun. Penurunan ini akan berisiko pada penurunan fungsi endokrin pankreas untuk memproduksi insulin dan berpengaruh terhadap kepekaan reseptor berkurang sehingga glukosa 
dalam darah meningkat. Usia dewasa berpengaruh terhadap tingginya diabetes distress. Diabetes tipe 1 maupun tipe 2 lebih sering terlihat pada populasi lansia. Hal ini menunjukkan semakin bertambahnya umur seseorang, maka fungsi dari organ-organ tubuhnya mulai berkurang yang rentang terhadap berbagai masalah kesehatan (Riyadi \& Sukarmin, 2008).

Usia dewasa biasanya lebih mampu mengontrol stres dibanding dengan usia kanak-kanak dan usia lanjut. Dengan kata lain orang dewasa biasanya mempunyai toleransi terhadap stres yang lebih baik. Semakin bertambahnya umur seseorang pengontrolan stress semakin menurun, sehingga umur sangat mempengaruhi tingkat distress seseorang (Putra, 2017).

Menurut Irawan (2010) jenis kelamin juga mejadi faktor yang mempengaruhi kejadian distress seseorang. Wanita lebih berisiko untuk terkena diabetes karena secara fisik wanita memiliki peluang untuk mengalami peningkatan indeks massa tubuh yang lebih besar. Sindroma siklus bulanan (pre-menstrual sindrome), pasca-menopause yang membuat distribusi lemak tubuh mudah terakumulasi akibat dari proses hormonal. Penelitian ini sejalan dengan teori diatas yaitu responden sebagian besar berjenis kelamin perempuan sebanyak 18 orang.

Hasil penelitian menunjukkan lansia lebih banyak mengalami distress sedang dalam rentang umur 55-59 tahun. Hal ini dipengaruhi oleh aktivitas berat yang dilakukan oleh lansia. Menurut peneliti semakin bertambahnya usia maka tingkat distress mengenai suatu penyakit yang dialaminya akan semakin tinggi. Pikiran mengenai adanya komplikasi penyakit lain menyebabkan lansia mudah mengalami distress diabetes. Hal ini juga dipengaruhi oleh jenuhnya lansia tersebut dalam melakukan kebiasaan baru dalam hidupnya yaitu menjalani terapi Diabetes Mellitus.

Dalam teori yang dikemukakakan oleh Azizah (2011) bahwa lama sakit seseorang berdampak pada kemampuan orang tersebut memahami kondisi dirinya dan mengendalikan dirinya terhadap keadaan kesehatannya dan mampu menekan timbulnya kecemasan pasien. Lama sakit berkaitan dengan proses adaptasi terhadap masalah yang dihadapi. Pemahaman yang dialami pasien terhadap sakitnya akan mendorong pasien untuk lebih mampu mengantisipasi munculnya kegawatan atau sesuatu hal yang mungkin terjadi pada diri pasien.

Penelitian ini sejalan dengan teori diatas yaitu sebagian besar responden mengalami DM selama 0-1 tahun yaitu sebanyak 21 orang. Sedangkan yang mengalami DM selama 4-5 tahun sebanyak 1 orang. Hal ini menunjukkan ada keterkaitan antara lama mengalami DM dengan tingkat distress yang dalami lansia. Semakin lama mengalami DM, pengontrolan stress semakin meningkat. Orang yang sudah lama mengalami DM mempunyai pengalaman lebih tentang cara mengontrol stress yang diakibatkan oleh penyakit DM, serta menilik terapi diabetes sesuai jadwal dan teratur.

Dalam penelitian ini peneliti berasumsi bahwa rata-rata lansia yang baru mengalami DM beumur lebih dari 50 tahun. Lansia lebih mudah mengalami distress akibat dari kondisi baru yang dialaminya dibandingkan lansia yang sudah lama mengalami DM. Hal ini menunjukkan bahwa pada saat sesorang mengetahui dirinya mengalami penyakit kronis, pikiran lebih terfokus kepada bagaimana cara mengatasi dan hidup dengan kondisi dengan penyakit kronis. Stresor dari dalam maupun dari 
lingkungan merupakan salah satu faktor yang mempengaruhi distress seseorang. berbagai stresor dapat mempengaruhi pengontrolan glukosa darah, pengontrolan glukosa yang buruk menyebabkan hormon kortisol meningkat sehingga dapat menyebabkan distress emosional yang berkepanjangan.

Terjadi penurunan distress lansia DM sebelum dilakukan senam ergonomis (pre test) dan setelah dilakukan senam ergonomis (post test) yaitu sebanyak 5 lansia $(16,67 \%)$ mengalami distress ringan sebelum dilakukan senam ergonomis dan tetap berada pada kategori distress ringan setelah dilakukan senam ergonomis. Sedangkan sebanyak 25 lansia $(83,33 \%)$ mengalami distress sedang sebelum intervensi senam ergonomis, kini mengalami penurunan distress setelah dilakukan senam ergonomis yaitu pada kategori ringan sebanyak 9 lansia (30\%) dan sebanyak 16 lansia (53,33\%) tetap mengalami distress sedang.

Menurut teori Wratsongko (2015) senam ergonomik adalah suatu teknik senam untuk mengembalikan atau membetulkan posisi dan kelenturan sistem saraf dan aliran darah, memaksimalkan suplai oksigen ke otak, membuka sistem kecerdasan, sistem keringat, sistem pemanas tubuh, sistem pembakaran asam urat, kolesterol, gula darah, asam laktat, chrystal oxalate, sistem konversi karbohidrat, sistem pembuatan elektrolit atau ozon dalam darah, sistem kesegaran tubuh dan sistem kekebalan tubuh dari energi negatif/virus, dan sistem pembuangan energi negatif dari tubuh (Wratsongko, 2015).

Gerakan yang terkandung dalam senam ergonomik adalah gerakan yang efektif, efisien, dan logis. Karena, rangkaian gerakannya merupakan rangkaian gerak yang di lakukan manusia sejak dulu sampai saat ini. Gerakan-gerakan senam ergonomik sesuai dengan kaidah-kaidah penciptaan tubuh yang diilhami dari gerakan shalat (Wratsongko, 2015).

Teori diatas sesuai dengan penelitian Lestari (2016) tentang pengaruh senam ergonomis terhadap distress diabetes, dengan responden 30 orang dan pemberian intervensi dilakukan selama 6 hari berturut-turut. Didapatkan hasil senam ergonomis tersebut senam ergonomis dapat menurunkan skor distress diabetes.

Senam ergonomik bermanfaat bagi tubuh. Melakukan senam ergonomik secara rutin dapat meningkatkan kekuatan otot dan efektifitas fungsi jantung, mencegah pengerasan pembuluh arteri dan melancarkan sistem pernafasan. Gerakan fisik teratur dapat meningkatkan kolesterol baik (HDL) yang betmanfaat bagi kesehatan jantung dan pembuluh darah. Senam ergonomik juga dapat menurunkan glukosa darah, mencegah osteoporosis dan penyakit lainnya (Wratsongko, 2015). Selain efek tersebut, senam ergonomis dapat membuat tubuh merasa rileks sehingga terjadi penurunan skor distress diabetes. Penurunan skor distress diabetes dapat diasumsikan terjadi penurunan sekresi kortisol (Guyton \& Hall, 2007).

Berdasarkan beberapa teori di atas, ada ketidaksesuaian yang ditemukan peneliti dengan pendapat para ahli. Berdasarkan hasil observasi dan wawancara, hasil penelitian menunjukkan faktor lingkungan dan dukungan keluarga sangat berpengaruh terhadap tingkat distress lansia. Dukungan keluarga yang tidak optimal dapat mempengaruhi terapi diabetes lansia tersebut. Pengobatan diabetes 
dapat terhambat dan menyebabkan kontrol glukosa terganggu. Dengan adanya senam yang dilakukan secara bersama-sama merupakan faktor yang mempengaruhi tingkat distress lansia DM. Tubuh yang segar dapat menghasilkan pikiran yang rileks serta jauh dari pandangan negatif sehingga dapat memotivasi lansia untuk melakukan terapi diabetes khususnya dengan terapi non farmakotika. Senam ergonomis tersebut lebih mudah dilakukan oleh lansia pada saat ada waktu luang di rumah masingmasing.

Berdasarkan hasil penelitian yang telah dilakukan selama 3 hari secara berturut-turut yang dilakukan selama 1 kali sehari pada sore hari diperoleh hasil nilai rata-rata pada pre test dan post test mengalami penurunan yaitu dari 2.423 menjadi 1.857. Dengan standar deviasi pada pre test yaitu 0.4500 dan pada post test yaitu 0.4337. Nilai maksimum pre test dan post test yaitu 2.9 dan 2.8. Berdasarkan hasil perhitungan menggunakan uji Wilcoxon pada sistem komputeriasai SPSS 16.0 didapatkan hasil yaitu $p$ value $=0.000<\alpha=0.05$, dimana hipotesis nol $\left(\mathrm{H}_{0}\right)$ ditolak atau hipotesis alternatif $\left(\mathrm{H}_{\mathrm{a}}\right)$ diterima yang artinya "Ada Pengaruh Senam Ergonomis terhadap Distress Lansia dengan Diabetes Mellitus di Kelurahan Selagalas wilayah kerja Puskesmas Cakranegara tahun 2019.”

Senam ergonomis pada pasien DM menjangkau seluruh aspek meliputi aspek kontrol glukosa darah, meningkatkan dan memperlancar sirkulasi darah dan mencegah terjadinya komplikasi. Selain efek tersebut, senam ergonomis dapat membuat tubuh merasa rileks sehingga terjadi penurunan skor distress diabetes. Penurunan skor distress DM dapat diasumsikan terjadi penurunan sekresi kortisol (Guyton \& Hall, 2007).

Manfaat senam ergonomis selain untuk menurunkan tingkat distress yang dialami, senam ini juga dapat menurunkan kadar gula darah lansia dengan Diabetes Mellitus. Dengan gerakan pengaturan nafas serta pemusatan pikiran pada saat melakukan gerakan merupakan acuan suksesnya senam ergonomis tersebut dalam mengatasi masalah distress lansia dengan Diabetes Mellitus (Wratsongko, 2015).

Teori tersebut diatas sejalan dengan hasil penelitian Lestari dkk (2016) dimana dapat disimpulkan bahwa senam ergonomis dapat menurukan skor distress Diabetes Mellitus yang dilakukan pada 30 responden dalam waktu 25 menit selama 6 hari berturut-turut. Senam ergonomis dapat menurunkan skor distress diabetes. Penurunan skor distress diabetes dapat membantu pasien untuk mengontrol glukosa darah. Dengan penurunan skor distress diabetes, pasien DM akan kembali memiliki motivasi untuk melakukan upaya pengendalian glukosa darah.

Melakukan senam ergonomik secara rutin dapat meningkatkan kekuatan otot dan efektifitas fungsi jantung, mencegah pengerasan pembuluh arteri dan melancarkan sistem pernafasan. Gerakan fisik teratur dapat meningkatkan kolesterol baik (HDL) yang bermanfaat bagi kesehatan jantung dan pembuluh darah. Senam ergonomik juga dapat menurunkan glukosa darah, mencegah osteoporosis dan penyakit lainnya (Wratsongko, 2015).

Pada saat dilakukan senam ergonomis efek yang ditimbulkan berupa rasa kesemutan pada daerah kaki dan sedikit panas, hal tersebut menandakan racun-racun dalam tubuh keluar sedikit demi 
sedikit. Racun-racun yang telah keluar memberikan efek rileksasi organ-organ dalam tubuh sehingga dapat mengatur pengontrolan glukosa darah, glukosa yang terkontrol yang pada akhirnya setelah dilakukan senam ergonomis efek negatif dari diabetes dapat berkurang (Sagiran, 2012).

Berdasarkan beberapa teori diatas sesuai dengan pendapat para ahli, dalam penelitian ini, ada beberapa ketidaksesuaian terhadap pendapat para ahli. Ketidaksesuaian tersebut diantaranya yaitu faktor lama mengalami DM, serta faktor minum obat DM. Lansia yang lama mengalami DM secara signifikan sudah mengetahui dan memahami tentang terapi serta perawatan untuk Diabetes Mellitus sehingga ada perubahan dalam skor distress tersebut. Sedangkan pada lansia yang baru mengalami DM, skor distress tidak menurun secara signifikan, dan masih dalam kategori yang sama. Senam yang dilakukan tidak dibarengi dengan terapi-terapi DM lainnya menjadi faktor penyebab skor distress tidak menurun secara signifikan. Pengaruh obat-obatan sangat penting bagi pengontrolan gula darah pasien. Konsumsi obat DM tidak teratur hingga tidak pernah mengkonsumis obat merupakan faktor yang mempengaruhi skor distress masih dalam rentang kategori yang sama.

\section{KESIMPULAN}

Sebelum dilakukan senam ergonomis sebagian besar responden mengalami distress sedang yaitu sebanyak 25 lansia. Setelah dilakukan senam ergonomis dari 25 lansia yang mengalami distress sedang, terjadi penurunan distress lansia yaitu pada kategori ringan sebanyak 9 lansia dan 16 lansia tetap mengalami distress sedang. Terdapat Pengaruh Senam Ergonomis terhadap Distress Lansia dengan Diabetes Mellitus di Kelurahan Selagalas wilayah kerja Puskesmas Cakranegara tahun 2019 dengan hasil perhitungan menggunakan Uji Wilcoxon yaitu $p$ value $=0,000<\alpha=0,05$. Dari penelitian ini dapat disimpulkan bahwa Senam Ergonomis berpengaruh terhadap distress lansia dengan Diabetes Mellitus di Kelurahan Selagalas wilayah kerja Puskesmas Cakranegara.

\section{DAFTAR PUSTAKA}

Azizah L.M. 2011. Keperawatan Jiwa (Aplikasi Praktik Klinik). Yogyakarta: Graha Ilmu.08/.../profilkesehatan-provinsi-nusa-tenggara-barat-2017.html. Diakses pada tanggal 6 Januari 2019 pukul 14.00 WITA.

Corwin, E.J. 2009. Buku Saku Patofisiologi. Jakarta: Aditya Media.

Guyton A.C. and J.E. Hall 2007. Buku Ajar Fisiologi Kedokteran. Edisi 9. Jakarta: EGC.

Hidayati, Aisyiyah. 2018. Pengaruh Senam Ergonomik Terhadap Tekanan Darah Lansia Hipertensi Di Desa Peresak Wilayah Kerja Puskesmas Sedau Tahun 2018. Mataram: Poletekkes Mataram; 2018.

Kowalak, JP, dkk. 2003. Buku Ajar Patofisiologi. Hartono A, editor. Jakarta: EGC

Lestari, DT, dan Wahyuni, Fitri. 2016. Pengaruh Senam Ergonomis Terhadap Distress Diabetes. [internet] Tersedia dalam https:// stikesyahoedsmg.ac.id/jurnal/?p=50. Diakses pada tanggal 7 Februari 2019 pukul 10.44 WITA. 
PERKENI. 2015. Pengelolaan Dan Pencegahan Diabetes Melitus Tipe 2 Di Indonesia 2015. [internet] tersedia dalam https://pbperkeni. or.id/wp-content/uploads/2019/01/4.-KonsensusPengelolaan-Pencegahan-Diabetes-melitus-tipe-2-di-Indonesia-PERKENI-2015.pdf. Diakses pada tanggal 10 Januari 2019 pukul 18.00 WITA.

Putra P, Ary Januar. 2016. Hubungan Diabetes Distress dengan Perilaku Perawatan Diri pada Penyandang Diabetes Melitus Tipe 2 di Wilayah Kerja Puskesmas Rambipuji Kabupaten Jember. [Internet] tersediadalam https://repository.un ej.ac.id/handle/123456789/76564. Diakses pada tanggal 14 Januari 2019 pukul 20.08 WITA RISKESDAS. 2018. Hasil Utama RISKESDAS 2018.

Sagiran. 2012. Mukjizat Gerakan Shalat. Jakarta Selatan: Qultum Media.

Wratsongko, Madyo. 2015. Mukjizat Gerakan Shalat \& Rahasia 13 Unsur Manusia. Jakarta Selatan: Mizania. 